\title{
Click-generated triazole based ferrocene-carbohydrate bioconjugates: A highly selective multisignalling probe for $\mathrm{Cu}(\mathrm{II})$ ions
}

\author{
ARUNABHA THAKUR, SINJINEE SARDAR and SUNDARGOPAL GHOSH* \\ Department of Chemistry, Indian Institute of Technology Madras, Chennai 600 036, India \\ e-mail: sghosh@iitm.ac.in
}

\begin{abstract}
Two $\mathrm{Cu}^{2+}$-specific colorimetric sensors, based on ferrocene-carbohydrate bioconjugates, 2 , $\mathrm{C}_{46} \mathrm{H}_{56} \mathrm{O}_{20} \mathrm{~N}_{6} \mathrm{Fe}$ and $3, \mathrm{C}_{28} \mathrm{H}_{33} \mathrm{O}_{10} \mathrm{~N}_{3} \mathrm{Fe}$ were designed and synthesized in good yields. Both the compounds, 2 and $\mathbf{3}$, behave as very selective and sensitive chromogenic and electrochemical chemosensor for $\mathrm{Cu}^{2+}$ ion in aqueous environment $\left(\mathrm{CH}_{3} \mathrm{CN} / \mathrm{H}_{2} \mathrm{O}(2: 8, v / v)\right.$. The analytical detection limit (ADL) for receptor 2 was $7.5 \times$ $10^{-7} \mathrm{M}$. The considerable changes in their absorption spectra of $\mathbf{2}$ and $\mathbf{3}$ are accompanied by the appearance of a new low energy (LE) peak at $630 \mathrm{~nm}\left(2: \varepsilon=1600 \mathrm{M}^{-1} \mathrm{~cm}^{-1}\right.$ and 3: $\left.822 \mathrm{M}^{-1} \mathrm{~cm}^{-1}\right)$. This is further accompanied by a strong colour change from yellow to dark green that allows the prospective for 'naked eye' detection of $\mathrm{Cu}^{2+}$ ion.
\end{abstract}

Keywords. Organometallic bioconjugates; $\mathrm{Cu}(\mathrm{II})$ cation sensor; chromogenic and electrochemical chemosensor.

\section{Introduction}

In recent years, there has been a growing need for constructing chemosensors for fast and economical monitoring of our environmental samples, especially for heavy metal ions. ${ }^{1}$ Copper is one of the heavy metals which is an essential element not only for life in mammals but also for plants. It also plays an important role in carbohydrate and lipid metabolism. ${ }^{2}$ It is the most significant metal ion in biological systems ${ }^{3}$ and also a significant environmental pollutant. ${ }^{4}$ Copper is implicated in inflammatory disorders ${ }^{5}$ and Alzheimer's disease. ${ }^{6}$ The $\mathrm{Cu}^{2+}$ proteins are involved in oxygen binding, electron transfer and the activation of small molecules. ${ }^{7}$ As a result, a strong interest exists in the development of selective $\mathrm{Cu}^{2+}$ sensors for biological and environmental applications. A variety of $\mathrm{Cu}^{2+}$ probes exhibiting either fluorescence 'on-off' or 'offon' signalling modes have been developed. ${ }^{8}$ However, colorimetric $\mathrm{Cu}^{2+}$ sensors offering ratiometric response are rare. ${ }^{9}$ Colorimetric probes are currently attracting area, since they can be tailored to allow 'naked eye' detection and ratiometric sensing ${ }^{10}$ of the analyte.

The most attractive way of achieving sensor design is to functionalize a receptor capable of both selective substrate binding with a metal centre and reporting on the recognition event through a variety of physical responses. Therefore, the design of redox-active receptors in which a change in electrochemical behaviour

*For correspondence can be used to monitor complexations of guest species is significant in molecular recognition. ${ }^{11-20}$ Thus, from a synthetic standpoint, ferrocene is a very convenient building block for redox-active ligand as it can be easily functionalized and incorporated in many structures. These facts, along with its electrochemical and UV-vis spectroscopic properties, demonstrate that ferrocene is a particularly attractive functional antenna in area of sensor for transition metals, p-block anions and organic molecules. For example, watersoluble ferrocenyl sugars are useful for the development of ferrocene-containing drugs. Further this, also been observed that some ferrocenyl sugars possess antimalarial activity. ${ }^{21}$ Carbohydrate-based chemosensors are chiral entities with hydroxyl groups and oxygen atoms, that form quite suitable cation binding sites. Thus, in the design of chemosensors, the incorporation of sugar molecules is a good strategy for capturing cations. ${ }^{22-24}$ In this article, we report the hostguest complexation properties of two triazole tethered ferrocenyl carbohydrate bioconjugates towards $\mathrm{Cu}^{2+}$ ion.

\section{Experimental}

\subsection{General procedures and instrumentation}

Perchlorate salts of $\mathrm{Li}^{+}, \mathrm{Na}^{+}, \mathrm{K}^{+}, \mathrm{Ag}^{+}, \mathrm{Ca}^{2+}, \mathrm{Mg}^{2+}$, $\mathrm{Co}^{2+}, \mathrm{Cu}^{2+}, \mathrm{Zn}^{2+}, \mathrm{Cd}^{2+}, \mathrm{Ni}^{2+}, \mathrm{Pb}^{2+}$, and $\mathrm{Hg}^{2+}$, 
propargyl bromide, butyl-lithium, tetramethylethylenediamine (TMEDA) purchased from Aldrich were used directly without further purification. Ferrocene, sodium ascorbate, sodium azide, acetonitrile purchased were of analytical grade and used without further purification. DMF purchased from Aldrich and freshly distilled prior to use. Chromatography was carried out on $3 \mathrm{~cm}$ of silica gel in a $2.5 \mathrm{~cm}$ diameter column. Column chromatography was carried out using 100 200 mesh silica gel. All the solvents were dried by conventional methods and distilled under a $\mathrm{N}_{2}$ atmosphere before use. Glycosyl azide ${ }^{25}$ and compounds 1a-b $\left[\mathrm{Fc}\left(\mathrm{CH}_{2} \mathrm{OCH}_{2} \mathrm{C} \equiv \mathrm{CH}\right)_{n}\right](\mathbf{1 a}: \mathrm{n}=2, \mathbf{1 b}: \mathrm{n}=1$, where $\mathrm{Fc}=$ ferrocene), were synthesized as per literature procedures. ${ }^{26}$ The cyclic voltammetry $(\mathrm{CV})$ and differential pulse voltammetry (DPV) were performed with a conventional three-electrode configuration consisting of glassy carbon as working electrode, platinum as an auxiliary electrode and $\mathrm{Ag} / \mathrm{Ag}^{+}$as a reference electrode. The experiments were carried out with a $10^{-4} \mathrm{M}$ solution of sample in $\mathrm{CH}_{3} \mathrm{CN}$ or $\mathrm{CH}_{3} \mathrm{CN} / \mathrm{H}_{2} \mathrm{O}$ (2/8) containing $0.1 \mathrm{M}\left[\left(n-\mathrm{C}_{4} \mathrm{H}_{9}\right)_{4} \mathrm{NClO}_{4}\right](\mathrm{TBAP})$ as supporting electrolyte. Deoxygenation of the solutions was achieved by bubbling nitrogen for at least $10 \mathrm{~min}$, and the working electrode was cleaned after each run. The cyclic voltammograms were recorded at a scan rate of $0.1 \mathrm{~V} \mathrm{~s}^{-1}$. The UV-vis spectra were carried out in $\mathrm{CH}_{3} \mathrm{CN}$ or $\mathrm{CH}_{3} \mathrm{CN} / \mathrm{H}_{2} \mathrm{O}(2 / 8)$ solutions at $\mathrm{c}=1 \times$ $10^{-4} \mathrm{M}$.

The ${ }^{1} \mathrm{H}$ and ${ }^{13} \mathrm{C}$ NMR spectra were recorded on Bruker $400 \mathrm{MHz}$ FT-NMR spectrometers, using tetramethylsilane as the internal reference. Electrospray ionization mass spectrometry (ESI-MS) measurements were carried out on a Qtof Micro YA263 HRMS instrument. The absorption spectra were recorded with a JASCO V-650 UV-vis spectrophotometer at $298 \mathrm{~K}$. The $\mathrm{CV}$ and DPV measurements were performed on a $\mathrm{CH}$ potentiostat model 660 B. Caution: Metal perchlorate salts are potentially explosive in certain conditions. All precautions should be taken while handling perchlorate salts.

\subsection{Synthesis of ferrocene-carbohydrate conjugates 2-3}

To a well-stirred solution of $1 \mathrm{a}(0.5 \mathrm{~g}, 1.55 \mathrm{mmol})$ and glycosyl azide $(3.31 \mathrm{~g}, 3.1 \mathrm{mmol})$ in $15 \mathrm{~mL}$ acetone/ $\mathrm{H}_{2} \mathrm{O}(2: 1)$, an aqueous solution of $\mathrm{CuSO}_{4} \cdot 5 \mathrm{H}_{2} \mathrm{O}(0.077 \mathrm{~g}$, $0.31 \mathrm{mmol}$ ) was added. To this resultant mixture freshly prepared sodium ascorbate solution $(0.122 \mathrm{~g}$, $0.62 \mathrm{mmol}$ ) was added and stirred at room temperature for $12 \mathrm{~h}$. $30 \mathrm{~mL}$ of ethyl acetate was added into the reaction mixture and the organic layer was washed several times with water and finally with brine $(15 \mathrm{~mL})$ and dried over anhydrous sodium sulphate. The solvent was removed under reduced pressure and the crude product was purified by silica gel column chromatography. Elution with EtOAc:hexane $(8: 2 v / v)$ yielded yellow 2 (1.42 g, 86\%).

Compound $\mathbf{3}$ was prepared in good yield following the procedure adopted for $\mathbf{2}$ from alkyne, $\mathbf{1 b}(0.5 \mathrm{~g}$, $1.96 \mathrm{mmol})$, glycosyl azide $(1.23 \mathrm{~g}, 1.96 \mathrm{mmol})$, aqueous $\mathrm{CuSO}_{4} \cdot 5 \mathrm{H}_{2} \mathrm{O}(0.097 \mathrm{~g}, 0.392 \mathrm{mmol})$ and sodium ascorbate $(0.149 \mathrm{~g}, 0.776 \mathrm{mmol})$. The crude product was purified by silica gel column chromatography and elution with EtOAc: hexane $(7: 2 v / v)$ to yield pure yellow, $3(0.98 \mathrm{~g}, 80 \%)$.

2: ${ }^{1} \mathrm{H}$ NMR $\left(\mathrm{CDCl}_{3}, 400 \mathrm{MHz}\right): \delta=7.71(\mathrm{~s}, 2 \mathrm{H}$, $\left.\mathrm{H}_{\text {triazole }}\right), 5.82$ (d, 2H, H-1), 5.45 (s, 2H, H-5), 5.17 (s, 2H, H-2) 5.01 (s, 2H, H-3), 4.51 (s, 2H, H-4), 4.21

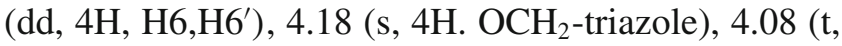
$\left.4 \mathrm{H}, \mathrm{H}_{\mathrm{Fc}}\right), 4.0\left(\mathrm{t}, 4 \mathrm{H}, \mathrm{H}_{\mathrm{Fc}}\right), 3.95\left(\mathrm{~s}, 4 \mathrm{H}, \mathrm{OCH}_{2}\right), 1.96-$ 1.81(d, $12 \mathrm{H}, \mathrm{OAc}) ;{ }^{13} \mathrm{C}$ NMR $\left(\mathrm{CDCl}_{3}, 100 \mathrm{MHz}\right): \delta=$ 170.5 (CO), 169.9 (CO), $169.4(\mathrm{CO}), 168.7(\mathrm{CO}), 146.0$ $\left(\mathrm{C}_{\text {triazole }}\right), 121.0\left(\mathrm{C}_{\text {triazole }}\right), 85.6(\mathrm{C}-1), 75.0(\mathrm{C}-2), 72.6$ $(\mathrm{C}-3), 71.7(\mathrm{C}-5), 70.3(\mathrm{C}-4), 68.8\left(\mathrm{C}_{\mathrm{Fc}}\right), 68.4\left(\mathrm{C}_{\mathrm{Fc}}\right)$, $67.6\left(\mathrm{C}_{\mathrm{Fc}}\right), 62.9(\mathrm{C}-6), 61.5\left(\mathrm{OCH}_{2}\right), 53.6\left(\mathrm{OCH}_{2}\right)$, 27.7, 20.5, 20.2, $19.1\left(\mathrm{CH}_{3} \mathrm{CO}\right)$; ESI MS, m/z (relative intensity): $1069\left(\mathrm{M}^{+}+1\right)$.

3: ${ }^{1} \mathrm{H}$ NMR $\left(\mathrm{CDCl}_{3}, 400 \mathrm{MHz}\right): \delta=7.68(\mathrm{~s}, 1 \mathrm{H}$, $\left.\mathrm{H}_{\text {triazole }}\right), 5.81(\mathrm{~d}, 1 \mathrm{H}, \mathrm{H}-1), 5.30(\mathrm{~m}, 1 \mathrm{H}, \mathrm{H}-5), 5.23$ (m, $1 \mathrm{H}, \mathrm{H}-2), 5.01(\mathrm{~s}, 1 \mathrm{H}, \mathrm{H}-3), 4.53$ (s, 1H, H-4), 4.26 (s, 2H, H6, H6') $4.21\left(\mathrm{~s}, 2 \mathrm{H}, \mathrm{OCH}_{2}\right.$-triazole), 4.06 (m, $\left.4 \mathrm{H}, \mathrm{H}_{\mathrm{Fc}}\right), 4.0\left(\mathrm{~s}, 5 \mathrm{H}, \mathrm{H}_{\mathrm{Fc}}\right), 3.99\left(\mathrm{~s}, 2 \mathrm{H}, \mathrm{OCH}_{2}\right), 2.08$ (s, 3H, OAc), 1.98 (s, 3H, OAc), 1.94 (s, 3H, OAc), 1.80 (s, 3H, OAc); ${ }^{13} \mathrm{C} \mathrm{NMR}\left(\mathrm{CDCl}_{3}, 100 \mathrm{MHz}\right): \delta=$ 170.2 (CO), 169.7 (CO), 169.3 (CO), 168.9 (CO), 146.1 $\left(\mathrm{C}_{\text {triazole }}\right), 120.9\left(\mathrm{C}_{\text {triazole }}\right), 85.6(\mathrm{C}-1), 75.0(\mathrm{C}-2), 72.5$ (C-3), $71.7(\mathrm{C}-4), 70.2(\mathrm{C}-5), 69.2\left(\mathrm{C}_{\mathrm{Fc}}\right), 68.6\left(\mathrm{C}_{\mathrm{Fc}}\right)$, $68.5\left(\mathrm{C}_{\mathrm{Fc}}\right), 67.6\left(\mathrm{C}_{\mathrm{Fc}}\right), 62.9(\mathrm{C}-6), 61.5\left(\mathrm{OCH}_{2}\right), 53.5$ $\left(\mathrm{OCH}_{2}\right), 29.6,27.7,20.6,19.0\left(\mathrm{CH}_{3} \mathrm{CO}\right) ; \mathrm{ESI} \mathrm{MS}, \mathrm{m} / \mathrm{z}$ (relative intensity): $650\left(\mathrm{M}^{+}+23\right)$.

\section{Results and discussion}

\subsection{Synthesis}

Precursors 1a-b were obtained following literature procedure. ${ }^{26}$ As shown in scheme 1, they undergo the 'click reaction' with glycosyl azide to generate compounds 2 and $\mathbf{3}$ in $86 \%$ and $80 \%$ yields, respectively. Compounds 2 and 3 have been characterized by ${ }^{1} \mathrm{H}$, ${ }^{13} \mathrm{C}$ NMR spectroscopy and ESI-MS spectrometry. Both the compounds $\mathbf{2}$ and $\mathbf{3}$ are moderately stable and 


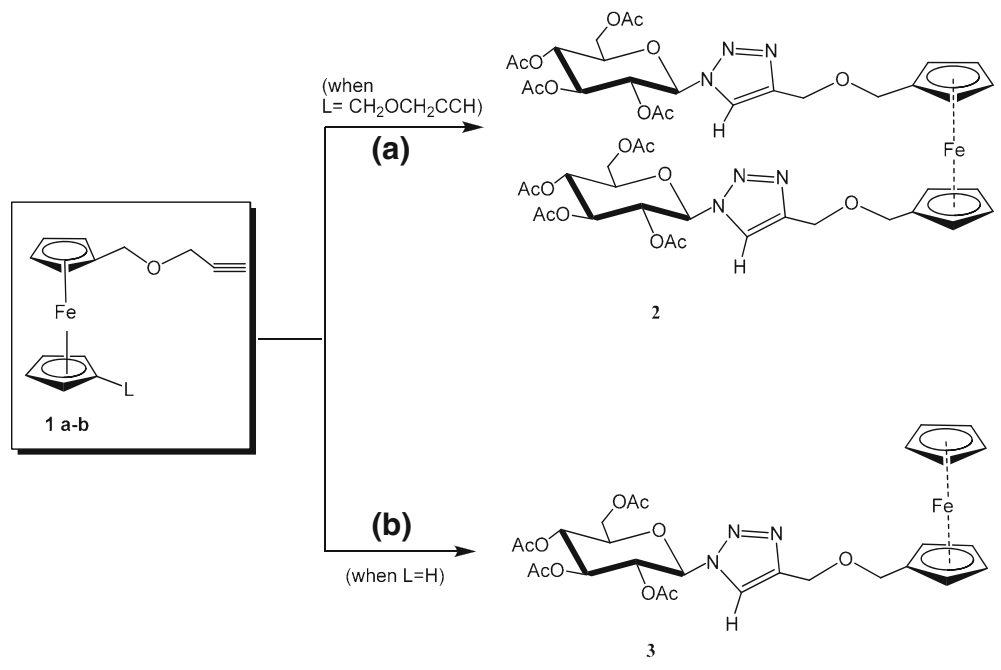

Scheme 1. Synthesis of mono and di-ferrocene-carbohydrate bioconjugates, 2 and 3. (a) 2 equiv. glycosyl azide, 0.1 equiv. $\mathrm{CuSO}_{4} \cdot 5 \mathrm{H}_{2} \mathrm{O}$, 0.25 equiv. Na Ascorbate, Acetone $/ \mathrm{H}_{2} \mathrm{O}(2: 1)$; (b) 1 equiv. glycosyl azide, 0.1 equiv. $\mathrm{CuSO}_{4} .5 \mathrm{H}_{2} \mathrm{O}, 0.25$ equiv. $\mathrm{Na}$ Ascorbate, Acetone $/ \mathrm{H}_{2} \mathrm{O}$ (2:1).

could be stored for several months. The complexation properties of the receptors $\mathbf{2}$ and $\mathbf{3}$ have been investigated by electrochemistry and UV-vis spectroscopic measurements.

\subsection{UV-vis absorption studies}

The UV-vis binding interaction studies of receptors 2 and 3 in $\mathrm{CH}_{3} \mathrm{CN}\left(1 \times 10^{-4} \mathrm{M}\right)$ against cation of environmental relevance, such as of $\mathrm{Li}^{+}, \mathrm{Na}^{+}, \mathrm{K}^{+}, \mathrm{Ag}^{+}$, $\mathrm{Ca}^{2+}, \mathrm{Mg}^{2+}, \mathrm{Zn}^{2+}, \mathrm{Ni}^{2+}, \mathrm{Co}^{+2}, \mathrm{Cd}^{2+}, \mathrm{Hg}^{2+}$ and $\mathrm{Pb}^{2+}$ as perchlorate salts, show selective response to $\mathrm{Cu}^{2+}$. The change in the UV-vis absorbance spectra of receptors 2 and 3 in $\mathrm{CH}_{3} \mathrm{CN}$ due to the step-wise addition of $\mathrm{Cu}^{2+}$ ion are shown in the figures 1 and 2, respectively. As shown in figures 1-2, a new and weak low-energy (LE) absorption band appeared at $\lambda=630 \mathrm{~nm}$ for both 2 $\left(\varepsilon=1600 \mathrm{M}^{-1} \mathrm{~cm}^{-1}\right)$ and $\mathbf{3}\left(\varepsilon=822 \mathrm{M}^{-1} \mathrm{~cm}^{-1}\right)$ was developed. These facts are responsible for the change of colour from yellow to dark green. In addition, one well-defined isosbestic point at $408 \mathrm{~nm}$ and $415 \mathrm{~nm}$ was observed for $\mathbf{2}$ and $\mathbf{3}$, respectively. The $\mathrm{Cu}^{2+}$ induced UV-vis response of $\mathbf{2}$ and $\mathbf{3}$ was almost unaffected in a background of environmentally relevant metallic cations.

The UV-vis spectral change suggests that the ferrocene moiety is oxidized upon complexation with
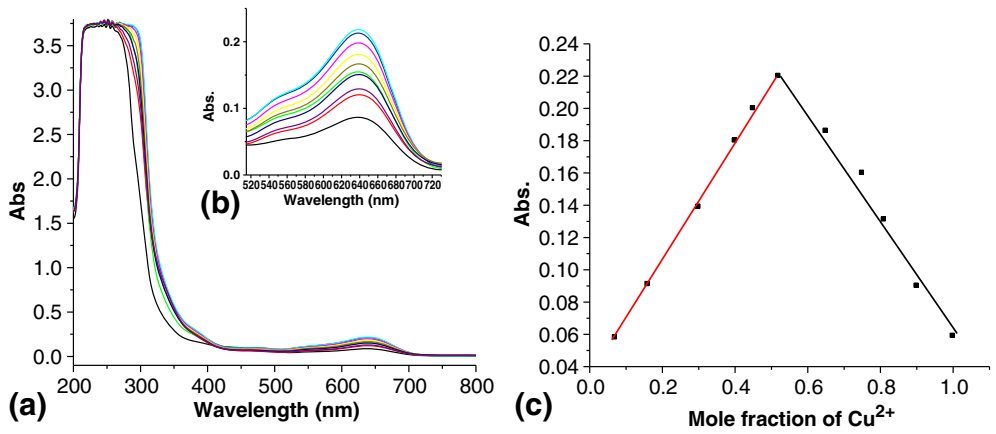

Figure 1. (a) Changes in the absorption spectra of $2\left(10^{-4} \mathrm{M}\right)$ in $\mathrm{CH}_{3} \mathrm{CN}$ upon addition of increasing amounts of $\mathrm{Cu}^{2+}$ up to 1 equivalent. (b) Expanded form of part a. (c) Job's plot for $\mathbf{2}$ and $\mathrm{Cu}^{2+}$, indicating the formation of 1:1 binding model. The total $[2]+\left[\mathrm{Cu}^{2+}\right]=1 \times$ $10^{-4} \mathrm{M}$. 

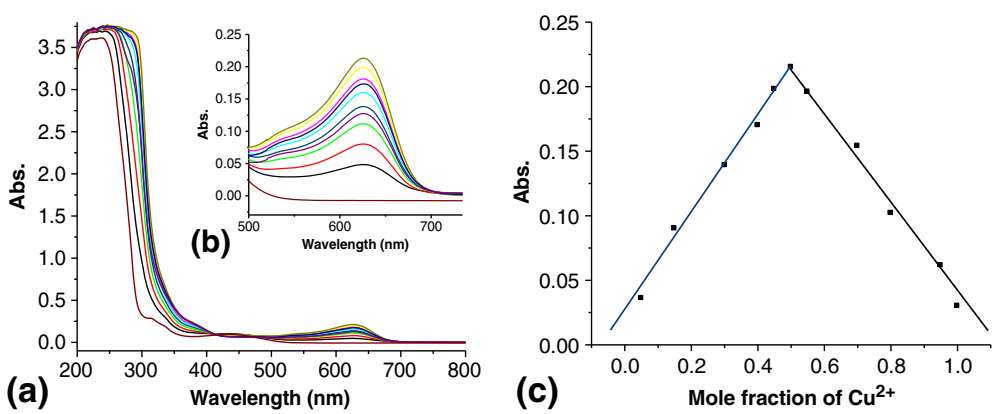

Figure 2. (a) Changes in the absorption spectra of $3\left(10^{-4} \mathrm{M}\right)$ in $\mathrm{CH}_{3} \mathrm{CN}$ upon addition of increasing amounts of $\mathrm{Cu}^{2+}$ up to 1 equivalent. (b) Expanded form of part a. (c) Job's plot for and $\mathrm{Cu}^{2+}$, indicating the formation of 1:1 binding model. The total $[3]+\left[\mathrm{Cu}^{2+}\right]=1 \times 10^{-4} \mathrm{M}$.

$\mathrm{Cu}^{2+}$ ion and the change of colour to deep green is characteristic of the ferrocenium ion formation. ${ }^{27} \mathrm{On}$ the basis of absorption intensity changes at $630 \mathrm{~nm}$ as a function of the amount of $\mathrm{Cu}^{2+}$ (inset figure $1 \mathrm{~b}$ ), it could be estimated that the stoichiometry of both $\mathbf{2}$ and 3 with $\mathrm{Cu}^{2+}$ is 1:1. This is further supported by the Job's plots (figures 1c for $\mathbf{2}$ and 2c for $\mathbf{3}$ ) and ESI-MS experiments, where a peak at $\mathrm{m} / \mathrm{z}=1131$ corresponds to $\left[2+\mathrm{Cu}^{2+}-\mathrm{H}^{+}\right]$and a small peak at $m / z=1230$ for $\left[2+\mathrm{Cu} \mathrm{ClO}_{4}\right]$ was observed. Similarly, for $\mathbf{3}$ a peak at $\mathrm{m} / \mathrm{z}=789$ was observed which corresponds to [3+ $\mathrm{Cu} . \mathrm{ClO}_{4}$ ] (supporting information, figures S3 and S4).

\subsection{Electrochemical studies}

Chemical sensors bearing ferrocene nuclei as part of the sensing unit have been broadly studied. Earlier, the complexation of ferrocene with a variety of binding ligands have been studied by cyclic voltammetry that shows a positive shift of the $\mathrm{Fe}(\mathrm{II}) / \mathrm{Fe}(\mathrm{III})$ redox couple as a result of metal-ligand complxation. ${ }^{28}$ The metal-recognition properties of receptors $\mathbf{2}$ and $\mathbf{3}$ were evaluated by cyclic (CV) and differential pulse voltammetry (DPV) analysis. The reversibility and relative oxidation potential of the redox process were
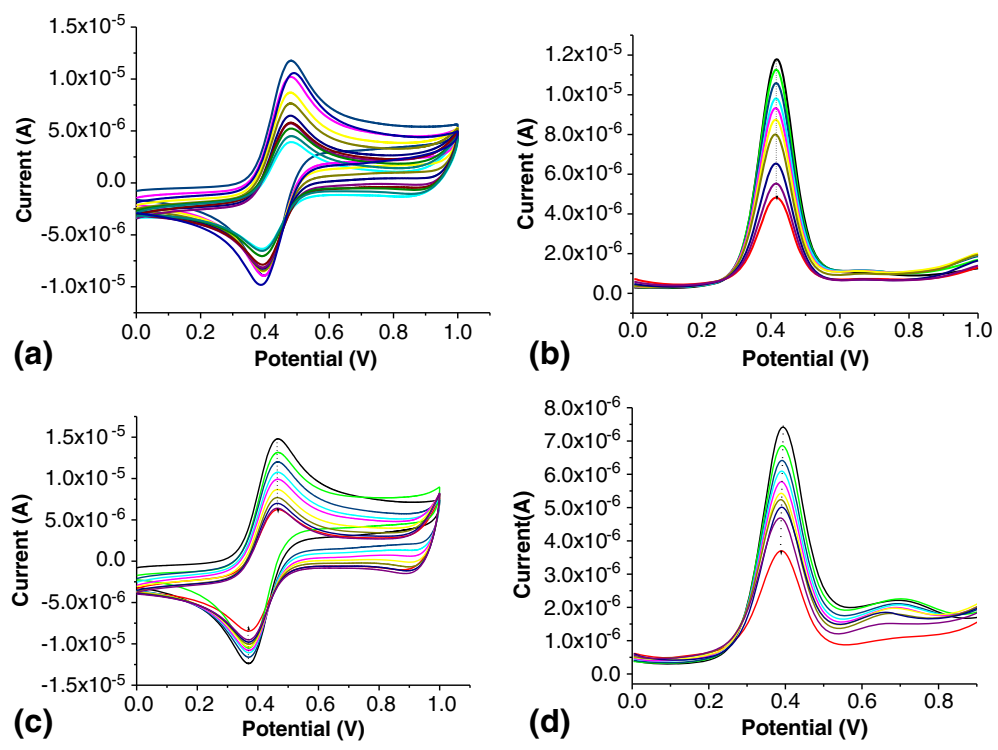

Figure 3. Evolution of the CV and DPV of $\mathbf{2}(\mathbf{a}$ and $\mathbf{b})$ and $\mathbf{3}(\mathbf{c}$ and $\mathbf{d})$ $\left(10^{-4} \mathrm{M}\right)$ in $\mathrm{CH}_{3} \mathrm{CN}$ upon addition of increasing amounts of $\mathrm{Cu}^{2+}$ metal cation up to 1 equivalent using $\left[(n-\mathrm{Bu})_{4}\right] \mathrm{ClO}_{4}$ as supporting electrolyte. Arrow indicates the movement of the wave during the experiments. 

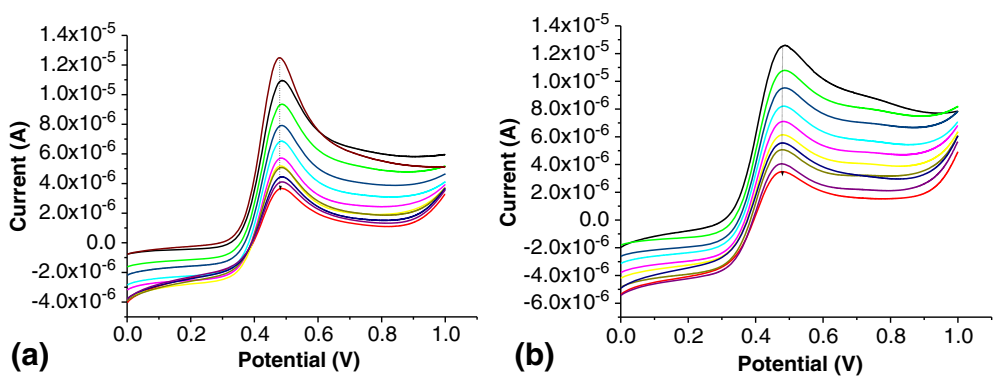

Figure 4. Evolution of LSV of 2 (a) and $3(\mathbf{b})\left(10^{-4} \mathrm{M}\right)$ in $\mathrm{CH}_{3} \mathrm{CN}$ upon addition of with $\mathrm{Cu}^{2+}$ ion using $\left[(n-\mathrm{Bu})_{4} \mathrm{~N}^{2} \mathrm{ClO}_{4}\right.$ as supporting electrolyte and scanned at $0.1 \mathrm{~V} \mathrm{~s}^{-1}$.

determined by $\mathrm{CV}$ and $\mathrm{DPV}$ in $\mathrm{CH}_{3} \mathrm{CN}$ solutions containing $0.1 \mathrm{M}\left[(n-\mathrm{Bu})_{4} \mathrm{~N}\right] \mathrm{ClO}_{4}$ as supporting electrolyte. Both the compounds $\mathbf{2}$ and $\mathbf{3}$ display a reversible one-electron oxidation process at $E_{1 / 2}=$ 0.433 and $0.415 \mathrm{~V}$, respectively due to the ferrocene/ferrocenium redox couple. No perturbation of the CV and DPV voltammograms of $\mathbf{2}$ and $\mathbf{3}$ were observed in the presence of several metal cations such as $\mathrm{Li}^{+}, \mathrm{Na}^{+}, \mathrm{K}^{+}, \mathrm{Ca}^{2+}, \mathrm{Mg}^{2+}, \mathrm{Zn}^{2+}, \mathrm{Ag}^{+}$, $\mathrm{Ni}^{2+}, \mathrm{Co}^{2+}, \mathrm{Cd}^{2+}, \mathrm{Hg}^{2+}$ and $\mathrm{Pb}^{2+}$ as their appropriate salts, even with large excess. However, as shown in figure $3 \mathrm{a}-\mathrm{d}$, the original peak gradually decreased upon step-wise addition of $\mathrm{Cu}^{2+}$ ion towards more cathodic current which indicate that free receptor is getting oxidized upon interaction with $\mathrm{Cu}^{2+}$ ion.

In addition, linear sweep voltammetry (LSV) studies carried out upon addition of $\mathrm{Cu}^{2+}$ to the $\mathrm{CH}_{3} \mathrm{CN}$ solution of receptor 2 . As shown in the figure 4 , a significant shift of the voltammetric wave towards more cathodic current was observed, indicating that this metal cation promotes the oxidation of the free receptor with its concomitant reduction to $\mathrm{Cu}^{+}$. This is in agreement with the CV and DPV (figure 3a-d). Remarkably, the redox response towards $\mathrm{Cu}^{2+}$ is also preserved in the presence of an aqueous environment $\left(\mathrm{CH}_{3} \mathrm{CN} / \mathrm{H}_{2} \mathrm{O}\right.$ $(2: 8, v / v))$.

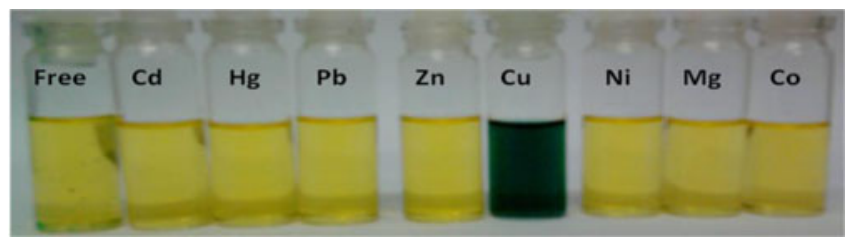

Figure 5. Visual features observed in $\mathrm{CH}_{3} \mathrm{CN}$ solution of $2\left(10^{-4} \mathrm{M}\right)$ after addition of 10 equivalent of different metal cation tested.

\subsection{Visual detection of $\mathrm{Cu}^{2+}$ ion}

When an excess of different metal cations $\left(\mathrm{Li}^{+}, \mathrm{Na}^{+}\right.$, $\mathrm{K}^{+}, \mathrm{Ag}^{+}, \mathrm{Ca}^{2+}, \mathrm{Mg}^{2+}, \mathrm{Cr}^{2+}, \mathrm{Zn}^{2+}, \mathrm{Ni}^{2+}, \mathrm{Fe}^{2+}, \mathrm{Co}^{2+}$, $\mathrm{Cd}^{2+}, \mathrm{Hg}^{2+}$ and $\mathrm{Pb}^{2+}$ ) as their perchlorate salt were separately added to a solution of $\mathbf{2}$ and $\mathbf{3}$ in $\mathrm{CH}_{3} \mathrm{CN}$ : $\mathrm{H}_{2} \mathrm{O}$ $\left(10^{-4} \mathrm{M}\right)$, no significant colour change observed, except for $\mathrm{Cu}^{2+}$. As shown in figure $5, \mathrm{Cu}^{2+}$ shows a drastic colour change from yellow to dark green. The sensing potential of $\mathbf{3}$ toward $\mathrm{Cu}^{2+}$ in solution is very similar to 2. This indicates that both $\mathbf{2}$ and $\mathbf{3}$ are highly selective colorimetric sensors for $\mathrm{Cu}^{2+}$ ion.

\section{Conclusion}

In this study, we have designed and synthesized two ferrocene-carbohydrate based organometallic bioconjugates, 2, $\mathrm{C}_{46} \mathrm{H}_{56} \mathrm{O}_{20} \mathrm{~N}_{6} \mathrm{Fe}$ and $3, \mathrm{C}_{28} \mathrm{H}_{33} \mathrm{O}_{10} \mathrm{~N}_{3} \mathrm{Fe}$ in good yields. They behave as selective and sensitive electrochemical as well as chromogenic receptors for the determination $\mathrm{Cu}^{2+}$ ion. These receptors showed high selectivity towards $\mathrm{Cu}^{2+}$ ion not only through spectrochemical and electrochemical probe but also amenable to the facile colorimetric sensing of $\mathrm{Cu}^{2+}$ ion, thus allowing the potential for 'naked-eye' detection over some other cations.

\section{Supplementary information}

The ${ }^{1} \mathrm{H},{ }^{13} \mathrm{C}$ and ESI-MS data of $\mathbf{2}$ and 3; electrochemical data for $\mathbf{2}$ and $\mathbf{3}$ upon titration with different metal ions; UV-Vis spectra upon titration with different metal ions; ESI-MS spectrum of $\left[\mathbf{2} \cdot \mathrm{Cu}^{2+}\right]$, $\left[3 . \mathrm{Cu}^{2+}\right]$ are given as Supplementary information. Figures S1-S6 as supporting material are available on www.ias.as.in/chemsci. 


\section{Acknowledgements}

Generous support of the Indo-French Centre for the Promotion of Advanced Research (IFCPARCEFIPRA), No. 4405-1, New Delhi is gratefully acknowledged. AT is grateful to the Council of Scientific and Industrial Research (CSIR), India for research fellowships.

\section{References}

1. Yari A and Afshari N 2006 Sens. Actuators B 199531

2. (a) Scheninberg H J and Morell G A 19731 Inorganic biochemistry (NewYork: Elsevier); (b) Dieter H H, Schimmelpfenning W and Mayer E 1999 Eur. J. Med. Res. 4 233; (c) Miller T, Sluis V B, Miller W and Pearson P 1999 Eur. J. Med. Res. 4293

3. (a) Linder M C and Hazegh-Azam M 1996 Am. J. Clin. Nutr. 63 797S; (b) Uauy R, Olivares $\mathrm{M}$ and Gonzalez M 1998 Am. J. Clin. Nutr. 67 952S; (c) Frausto da Silva J J R and Williams R J P 1993 The biological chemistry of elements: The inorganic chemistry of life (Oxford: Clarendon Press)

4. (a) Sarkar B 1981 Met. Ions Biol. Syst. 12 233; (b) Yardim M F, Budinova T, Ekinci E, Petrov N, Razvigorova M and Minkova V 2003 Chemosphere 52 835

5. Alan J L 1984 Inflamm. Res. 15513

6. Barnham K J, Masters C L and Bush A I 2004 Nat. Rev. Drug Discovery 3205

7. Frieden E, Osaki S and Kobayashi H 1965 J. Gen. Physiol. 49213

8. (a) Ghosh P, Bharadwaj P K, Mandal S and Ghosh S 1996 J. Am. Chem. Soc. 118 1553; (b) Kramer R 1998 Angew. Chem. Int. Ed. 37 772; (c) Rurack K, Kollmannsberger M, Resch-Genger U and Daub J 2000 J. Am. Chem. Soc. 122 968; (d) Kaur S and Kumar S 2002 Chem. Commun. 2840; (e) Roy B C, Chandra B, Hromas D and Mallik S 2003 Org. Lett. 5 11; (f) Xiao Y and Qian X 2003 Tetrahedron Lett. 44 2087; (g) Zheng Y, Orbulescu J, Ji X, Andreopoulos F M, Pham S M and Leblanc R M 2003 J. Am. Chem. Soc. 125 2680; (h) Wu Q and Anslyn E V 2004 J. Am. Chem. Soc. 12614682

9. (a) Gunnlaugsson T, Leonard J P and Murray N S 2004 Org. Lett. 6 1557; (b) Royzen M, Dai Z and Canary J W 2005 J. Am. Chem. Soc. 127 1612; (c) Kaur N and Kumar S 2006 Tetrahedron Lett. 47 4109; (d) Martinez R, Zapata F, Caballero A, Espinosa A, Tarraga A and Molina P 2006 Org. Lett. 8 3235; (e) Mu H, Gong R,
Ma Q, Sun Y and Fu E 2007 Tetrahedron Lett. 48 5525; (f) Weng Y-Q, Yue F, Zhong Y-R and Ye B-H 2007 Inorg. Chem. 467749

10. Kubo Y M, Ikeda Y M, Takeuchi M, Shinkai S, Yamaguchi S and Tamao K 2003 Angew. Chem. Int. Ed. 42 2036; (b) Raker J and Glass T E 2002 J. Org. Chem. 67 6113; (c) Fu H, Loo B H, Xiao D, Xie R, Ji X, Yao J, Zhang B and Zhang L 2002 Angew. Chem. Int. Ed. 41 962; (d) Mello J V and Finney N S 2001 Angew. Chem. Int. Ed. 40 1536; (e) Takakusa H, Kikuchi K, Urano Y, Sakamoto S, Yamaguchi K and Nagano T 2002 J. Am. Chem. Soc. 1241653

11. Gokel G W 1992 Chem. Soc. Rev. 2139

12. Beer P D 1992 Adv. Inorg. Chem. 3979

13. Jorgensen T, Hansen T K and Becher J 1994 Chem. Soc. Rev. 2341

14. Fabrizzi L and Poggi A 1995 Chem. Soc. Rev. 197

15. Kaifer A E and Mendoza S, 19961701 In: Comprehensive supramolecular chemistry: G W Gokel (ed) (Oxford: Pergamon)

16. Boulas P L and Echegoyen M L 1998 Angew. Chem. Int. Ed. Engl. 37216

17. Beer P D and Gale P A 1998 Adv. Phys. Org. Chem. 311

18. Beer P D 1998 Acc. Chem. Res. 3171

19. Beer P D, Gale P A and Chen G Z 1999 Coord. Chem. Rev. 3185

20. Beer P D and Gale P A 2001 Angew. Chem. Int. Ed. Engl. 40485

21. Itoh T, Shirakami S, Ishida N, Yamashita Y, Yoshida T, Kim H S and Wataya Y 2000 Bioorg. Med. Chem. Lett. 101657

22. Yuasa H, Miyagawa N, Izumi T, Nakatani M, Izumi M and Hashimoto H 2004 Org. Lett. 61489

23. Singhal N K, Ramanujam B, Mariappanadar V and Rao C P 2006 Org. Lett. 83525

24. Xie J, Ménand M, Maisonneuve S and Métivier R 2007 J. Org. Chem. 725980

25. Kumar R, Tiwari P, Maulik P R and Misra A K 2006 Eur. J. Org. Chem. 74

26. Thakur A, Adarsh N N, Chakraborty A, Devi M and Ghosh S 2010 J. Organomet. Chem. 6951059

27. Lloveras V, Caballero A, Tárraga A, Velasco M D, Espinosa A, Wurst K, Evans D J, Vidal-Gancedo J, Rovira C, Molina P and Veciana J 2005 Eur. J. Inorg. Chem. 2436

28. (a) López J L, Tárraga A, Espinosa A, Velasco M D, Molina P, Lloveras V, Vidal-Gancedo J, Rovira C, Veciana J, Evans D J and Wurst K 2004 Chem. Eur. J. 10 1815; (b) Martínez R, Espinosa A, Tárraga A and Molina P 2005 Org. Lett. 7 5869; (c) Zapata F, Caballero A, Espinosa A, Tárraga A and Molina P 2007 Org. Lett. 92385 